\title{
Therapeutic Drug Monitoring of Gentamicin: Evaluation of Five Nomograms for Initial Dosing at Al-Amiri Hospital in Kuwait
}

\author{
Yousef Al-Lanqawi $^{\mathrm{a}}$ Phillip Capps ${ }^{\mathrm{d}}$ Mohamed Abdel-hamid $^{\mathrm{e}}$ \\ Kefaya Abulmalek ${ }^{b}$ Dotun Phillips ${ }^{\mathrm{e}}$ Kamal Matar $^{\mathrm{f}}$ Prem Sharma $^{\mathrm{g}}$ Anil Thusu $^{\mathrm{c}}$ \\ Departments of ${ }^{\text {P Pharmacy, }}{ }^{\mathrm{b}}$ Intensive Care and ${ }^{\mathrm{C}}$ Medicine, Al-Amiri Hospital, Ministry of Health, and \\ Departments of ${ }^{\mathrm{d}}$ Pharmacy Practice, ${ }^{e}$ Pharmaceutical Chemistry and ${ }^{\mathrm{f}}$ Applied Therapeutics, Faculty of Pharmacy, \\ and ${ }^{9}$ Health Sciences Computer Center, Kuwait University, Kuwait
}

\section{Key Words}

Gentamicin • Initial dosing nomograms • Pharmacokinetics the Thomson guidelines showed that $21 \%$ of patients were underdosed. Conclusion: The results show that a large number of patients (37-63\%) were outside the target ranges in all initial gentamicin dosing methods evaluated in this study. Therefore, serum concentration measurement can be advised to assist in the optimization of gentamicin dose selection.

Copyright $\odot 2007$ S. Karger AG, Basel

\section{Introduction}

The aminoglycoside gentamicin is commonly used to treat gram-negative infections and continues to be widely applied in hospitalized patients $[1,2]$. However, the occurrence of nephrotoxicity and ototoxicity in a significant number of patients has been the main drawback [3, 4]. Hence, it is important to devise dosing regimens for gentamicin that both optimize its clinical efficacy and minimize its toxicity. Nephrotoxicity has generally been associated with trough gentamicin concentration that exceeds $2.0 \mathrm{mg} \cdot \mathrm{l}^{-1}$ [5]. Traditionally, gentamicin is administered in multiple daily doses (once every 8 or $12 \mathrm{~h}$ ), with the peak concentration measured 30-60 min after the end of intravenous infusion and the trough concentration measured immediately before the next dose [5]. Based on this dosing method, clinicians aim to achieve traditional target peak and trough concentrations of 5-10

\section{KARGER}

Fax +4161306 1234

E-Mail karger@karger.ch

www.karger.com
(C) 2007 S. Karger AG, Basel

1011-7571/07/0165-0348\$23.50/0

Accessible online at:

www.karger.com/mpp
Yousef Al-Lanqawi

PO Box 491

32005 Hawaly (Kuwait)

Tel. +965 245 0005, ext. 5079/7016

E-Mail yousefl@hsc.edu.kw 
and 1-2 $\mathrm{mg} \cdot \mathrm{l}^{-1}$, respectively [6]. Recently, once-daily dosing strategies have been recommended in many clinical settings. The rationale for these strategies is that high peak serum concentrations enhance the concentrationdependent bactericidal activity of gentamicin against gram-negative infections $[7,8]$ and that this drug has a postantibiotic effect that is longer when the peak drug level is higher [9]. Once-daily gentamicin has an equivalent efficacy and a trend towards reduced toxicity compared with traditional dosing methods [10-12].

In Kuwait, the clinical practice of prescribing gentamicin to hospitalized patients is based on the traditional multiple daily dosing method, where gentamicin is empirically dosed. Usually the empirical dose of gentamicin is $80 \mathrm{mg}$, administered every $8 \mathrm{~h}$ (if renal function is nor$\mathrm{mal}$ ), and 80 or $60 \mathrm{mg}$ is administered every $12 \mathrm{~h}$ for patients with impaired renal function. Various dosing charts and nomograms have been proposed and are available to the clinicians in estimating initial dosage regimen in patients having normal or compromised renal function. These are: Thomson guidelines [6], Mawer nomogram [13], rule of eights [14], Hull-Sarubbi table [15] and Dettli method [16]. These nomograms are based on statistical correlations between aminoglycoside elimination rate constant and estimates of renal function (usually creatinine clearance). Many reports have shown that a wide intersubject variability in gentamicin disposition even within apparently homogeneous subgroups exists [17]. It is particularly important to assess the most reliable nomograms for initial gentamicin dosing that achieves the predetermined gentamicin target levels and can be rationally implemented. This paper presents a comparative retrospective study of five gentamicin initial dosing nomograms with respect to the predicted peak and trough gentamicin concentrations.

\section{Materials and Methods}

\section{Patients and Data Collection}

The present study was based on retrospectively collected data (from 1999 to 2004) from 56 patients who had gentamicin serum concentrations measured at the biochemistry laboratory during therapy for prophylaxis or treatment of suspected or confirmed gram-negative infections. Adult inpatients who received intravenous gentamicin as a part of routine therapy were considered eligible for the study if: (a) they had a minimum of two measured steady-state serum gentamicin concentrations (peak and trough); (b) they had gentamicin level drawn around the third or greater dose of an unchanged gentamicin dosing regimen; (c) the collection times of when the samples were drawn were documented, and (d) they had a predose sample of serum creatinine concen- tration $\left(\mathrm{C}_{\mathrm{cr}}\right)$ recorded. Patients were excluded from the study if: (a) demographic data such as age and weight were not available; (b) they had experienced changing renal function (defined as $\geq 25 \mu \mathrm{mol} \cdot \mathrm{l}^{-1}$ change in serum $\mathrm{C}_{\mathrm{cr}}$ ); (c) serum gentamicin had not been at steady state, and (d) they received dialysis treatment.

\section{Administration of Gentamicin}

The initial dosages of gentamicin were decided by the attending clinician and ranged from 1.6 to $5.7 \mathrm{mg} \cdot \mathrm{kg}^{-1}$ of the total body weight; the dosing intervals ranged from 8 to $12 \mathrm{~h}$. Gentamicin was administered by slow intravenous injection over 1-3 min.

\section{Blood Sampling and Determination of Gentamicin Serum} Concentrations

Blood samples were collected immediately or within a halfhour before dosing (trough level) and $1 \mathrm{~h}$ after an intravenous dose (peak level). Gentamicin serum concentrations were measured on the Cobas Integra systems using a fluorescent principle of fluorescence polarization. The precision for the gentamicin assay (percentage coefficient of variation) was $<5 \%$ for the concentrations of $0.1-9.8 \mathrm{mg} \cdot \mathrm{1}^{-1}$.

\section{Calculations: Creatinine Clearance}

The creatinine clearance was estimated for each patient using the Siersbaek-Nielsen method [18], by applying the patient's age, weight and serum $\mathrm{C}_{\mathrm{cr}}$. The $\mathrm{C}_{\mathrm{cr}}$ level was analyzed by Beckman (Beckman Instrument, Synchron CXR system, USA) using a single reagent alkaline-picrate kinetic assay. The coefficient of variation of the creatinine assay was $>4 \%$, over the range of patient values $\left(53-650 \mu \mathrm{mol} \cdot \mathrm{l}^{-1}\right)$.

\section{Kinetic Analysis: Individual Gentamicin Kinetic Parameter}

Estimation (Elimination Rate Constant and Volume of

Distribution)

The elimination rate constant $\left(\mathrm{K}_{\mathrm{e}}\right)$ and volume of distribution $\left(\mathrm{V}_{\mathrm{d}}\right)$ were calculated for each patient using the Data Kinetics program (MDK Inc., USA, 2001), which is based on a one-compartment open model utilizing a modified two-point Sawchuk-Zaske method [19]. $\mathrm{K}_{\mathrm{e}}$ was determined by:

$$
\mathrm{K}_{\mathrm{e}}=\ln \left(\mathrm{C}_{\mathrm{PK}} / \mathrm{C}_{\mathrm{TR}}\right) / \mathrm{T}
$$

where $\mathrm{C}_{\mathrm{PK}}$ and $\mathrm{C}_{\mathrm{TR}}$ are the measured peak and trough concentrations (milligrams per liter) and $\mathrm{T}$ (hours) is the time interval between the measured peak and trough levels.

$\mathrm{V}_{\mathrm{d}}$ was calculated as:

$$
\mathrm{V}_{\mathrm{d}}=\mathrm{D} \cdot\left(1-\mathrm{e}^{-\mathrm{ke} \cdot \mathrm{t}}\right) /\left(\mathrm{t} \cdot \mathrm{k}_{\mathrm{e}}\right) \cdot\left(\mathrm{C}_{\max }-\mathrm{C}_{\min } \cdot \mathrm{e}^{-\mathrm{ke} \cdot \mathrm{t}}\right)
$$

where $\mathrm{D}$ is the administered dose (milligrams), $\mathrm{t}$ is the infusion time, $\mathrm{C}_{\max }$ is the peak concentration (milligrams per liter) measured $1 \mathrm{~h}$ after intravenous bolus dose and extrapolated back to the time immediately after intravenous bolus dose, and $\mathrm{C}_{\min }$ is the measured trough concentration extrapolated to the end of the dosage interval.

\section{Calculation of the Steady-State Peak and Trough}

Concentrations

The $\mathrm{K}_{\mathrm{e}}$ and $\mathrm{V}_{\mathrm{d}}$ determined from the serum concentration time data were used to calculate the steady-state peak ( $1 \mathrm{~h}$ after an intravenous gentamicin dose) and trough (immediately before the 
gentamicin dose) concentrations resulted from the dosage regimens recommended by the five nomograms (outlined below). The peak and trough concentrations at steady state were calculated using the following equation:

$$
\mathrm{C}_{\mathrm{ss}}=\left(\mathrm{D} / \mathrm{V}_{\mathrm{d}}\right) \cdot \mathrm{e}^{-\mathrm{ke} \cdot \mathrm{t}_{1}} \cdot\left[1 /\left(1-\mathrm{e}^{-\mathrm{ke} \cdot \tau}\right)\right]
$$

where $\mathrm{C}_{\mathrm{ss}}$ is the steady-state concentration and $\mathrm{t}_{1}$ is the time between the end of intravenous injection and the time where the steady-state peak concentrations can be predicted.

The equation was used to calculate the steady-state peak and trough concentrations. For the peak level prediction, $\mathrm{t}_{1}$ is equal to $1 \mathrm{~h}$ and for trough level prediction, time is equal to $\tau$ (dosing interval).

\section{Nomograms}

The Thomson guidelines [6] were used to determine the maintenance dose for each patient. For both Thompson guidelines and Mawer nomogram [13] age, sex, weight and creatinine clearance were required for calculation.

With the rule of eights [14] doses of $1.0-1.76 \mathrm{mg} \cdot \mathrm{kg}^{-1}$ are recommended to be administered at variable intervals, depending on the $\mathrm{C}_{\mathrm{cr}}$ value. In this study, a medium dose of $1.33 \mathrm{mg} \cdot \mathrm{kg}^{-1}$ was fixed for all patients. The doses were rounded up to the nearest practical dose, i.e. $40,60,80,100,120,140$ and $160 \mathrm{mg}$. For patients with normal $\mathrm{C}_{\mathrm{cr}}\left(<124 \mu \mathrm{mol} \cdot \mathrm{l}^{-1}\right)$ the dosage interval was 8 h. For patients with renal impairment, the dosing interval was determined by multiplying the $\mathrm{C}_{\mathrm{cr}}$ value by 8 and rounding off to more convenient practical intervals of 12,18 and $24 \mathrm{~h}$. The input data required for this method are weight and serum $\mathrm{C}_{\mathrm{cr}}$.

For the dosing table the Hull-Sarubbi table [15] was used to determine the loading and maintenance doses. A fixed loading dose of $1.75 \mathrm{mg} \cdot \mathrm{kg}^{-1}$ was selected to provide a peak serum concentration in the range of $5-7 \mathrm{mg} \cdot \mathrm{l}^{-1}$ for all patients. A maintenance dose expressed as percentage of the loading dose to continue peak serum concentration indicated in this method was selected, according to the desired dosage interval and the patient's creatinine clearance. The doses were rounded up to the nearest practical dose, i.e. 40, 60, 80, 100, 120, 140 and $160 \mathrm{mg}$. The input data required are age, sex, weight and creatinine clearance.

For the patients' calculated creatinine clearance the Dettli method [16] was used to estimate the $\mathrm{K}_{\mathrm{e}}$ and the patient's body weight to estimate the $V_{d}$. These values were calculated according the following formulae:

$$
\begin{aligned}
& \mathrm{K}_{\mathrm{e}}=0.0024 \cdot \text { creatinine clearance }+0.01 \\
& \mathrm{~V}_{\mathrm{d}}=0.25 \mathrm{l} \cdot \mathrm{kg}^{-1}
\end{aligned}
$$

The $\mathrm{K}_{\mathrm{e}}$ and $\mathrm{V}_{\mathrm{d}}$ were used to calculate the dosage regimen, which would achieve target peak concentrations of $5-10 \mathrm{mg} \cdot \mathrm{l}^{-1}$ and trough concentrations $<2 \mathrm{mg} \cdot \mathrm{l}^{-1}$.

\section{Statistical Analysis}

The five nomograms were evaluated by comparing the predicted gentamicin concentrations with the predefined one-hour postdose drug concentration in the range of $5-10 \mathrm{mg} \cdot \mathrm{l}^{-1}$ and that of the trough should be the range of $0.5-2 \mathrm{mg} \cdot \mathrm{1}^{-1}$. The patient data, corresponding to these target levels, were assessed on the basis of: (i) both peak and trough concentrations being within the expected range; (ii) only peak concentration within the range, and (iii) only trough concentration within the range. Descriptive statistics are expressed as means \pm standard deviation (SD) and range. The percentages were used to evaluate the predicted concentrations achieved from each nomogram at all target ranges. Cochran's test [20] served to compare the predicted concentration values achieved by the five nomograms and $\chi^{2}$ test [21] was used to compare the values from the individual nomograms. Data management and statistical analysis were carried out using Statistical Package for Social Sciences software (PC version 11.5). A level of $\mathrm{p}<0.05$ was considered as statistically significant.

\section{Results}

\section{Demographics}

Of the 56 patients, 21 were female and 35 male. The mean ( \pm SD) values of age, weight and serum $C_{c r}$ were 52 \pm 16 years, $67 \pm 14 \mathrm{~kg}$ and $85 \pm 28 \mu \mathrm{mol} \cdot \mathrm{l}^{-1}$, respectively.

\section{Creatinine Clearance}

The calculated creatinine clearance values ranged from 27 to $148 \mathrm{ml} \cdot \mathrm{min}^{-1}$ with a mean of $69(\mathrm{SD}=28)$. Most $(\mathrm{n}=44)$ of the patients had normal renal function (creatinine clearance $>60 \mathrm{ml} \cdot \mathrm{min}^{-1}$ ). However, a few $(\mathrm{n}=12)$ patients were recognized as having a reduction in renal function (creatinine clearance $<40 \mathrm{ml} \cdot \mathrm{min}^{-1}$ ). The dose and dosing intervals calculated by the five nomograms are presented in table 1 . The means $\pm \mathrm{SD}$ of $\mathrm{K}_{\mathrm{e}}$ and $\mathrm{V}_{\mathrm{d}}$ values were $0.239 \pm 0.083 \mathrm{~h}^{-1}$ (range $=0.075-$ $\left.0.417 \mathrm{~h}^{-1}\right)$ and $0.27 \pm 0.09 \mathrm{l} \cdot \mathrm{kg}^{-1}($ range $=0.14-0.57 \mathrm{l} \cdot$ $\mathrm{kg}^{-1}$ ), respectively.

\section{Steady-State Gentamicin Peak and Trough \\ Concentrations}

The means \pm SD of the measured gentamicin peak and trough concentrations were $4.5 \pm 1.5 \mathrm{mg} \cdot \mathrm{l}^{-1}$ (range $\left.=1.6-8.3 \mathrm{mg} \cdot \mathrm{l}^{-1}\right)$ and $1.0 \pm 0.6 \mathrm{mg} \cdot \mathrm{l}^{-1}($ range $=0.3-2.7$ $\left.\mathrm{mg} \cdot \mathrm{l}^{-1}\right)$, respectively. The distributions of the measured steady-state peak and trough concentrations achieved from empirical dosing are illustrated in figure $1(n=41)$. A majority of the study patients did not achieve steadystate serum concentrations in the therapeutic range and showed wide interpatient variability in the peak and trough levels. The distributions of the predicted steadystate peak and trough concentrations for the five nomograms are also illustrated in figure 1 . The percentages of peaks plus troughs, peaks only and troughs only within the target ranges are shown in table 2 . The peak and trough concentrations achieved using the Thomson guidelines ranged from 2.8 to $12.7 \mathrm{mg} \cdot \mathrm{l}^{-1}$ and 0.1 to $4 \mathrm{mg} \cdot \mathrm{l}^{-1}$, respectively, whereas those with the Mawer 
Table 1. Distribution of patients for each recommended dose and dosing intervals achieved by empirical dosing and five nomograms

\begin{tabular}{|c|c|c|c|c|c|c|c|}
\hline \multirow{2}{*}{$\begin{array}{l}\text { Dose } \\
\text { mg }\end{array}$} & \multirow{2}{*}{$\begin{array}{l}\text { Interval } \\
\mathrm{h}\end{array}$} & \multicolumn{6}{|c|}{ Number of patients with each dosing method } \\
\hline & & $\begin{array}{l}\text { empirical } \\
\text { dosing }\end{array}$ & Thomson & Mawer & $\begin{array}{l}\text { rule of } \\
\text { eights }\end{array}$ & $\begin{array}{l}\text { Hull- } \\
\text { Sarubbi }\end{array}$ & Dettli \\
\hline \multirow[t]{4}{*}{60} & 6 & & & & & & \\
\hline & 8 & 7 & & & 6 & 1 & \\
\hline & 12 & & 2 & & 1 & 3 & 1 \\
\hline & 24 & & & & & & \\
\hline \multirow[t]{4}{*}{80} & 6 & & & & & & \\
\hline & 8 & 34 & 4 & 4 & 28 & 8 & 4 \\
\hline & 2 & 14 & 1 & 3 & 1 & 3 & 2 \\
\hline & 24 & & 1 & & & & 2 \\
\hline \multirow[t]{4}{*}{100} & 6 & & & & & & \\
\hline & 8 & 1 & 13 & & 12 & 22 & 5 \\
\hline & 12 & & 3 & & 1 & 2 & 6 \\
\hline & 24 & & 1 & & & & 2 \\
\hline \multirow[t]{4}{*}{120} & 6 & & & & & & 1 \\
\hline & 8 & & 6 & 11 & 4 & 11 & 7 \\
\hline & 12 & & 2 & & & & 4 \\
\hline & 24 & & 1 & & & & \\
\hline \multirow[t]{4}{*}{140} & 6 & & & & & & 3 \\
\hline & 8 & & 19 & & 3 & 4 & 5 \\
\hline & 12 & & 2 & & & & 1 \\
\hline & 24 & & 1 & & & & 1 \\
\hline \multirow[t]{4}{*}{160} & 6 & & & & & & 3 \\
\hline & 8 & & & 38 & & 2 & 9 \\
\hline & 12 & & & & & & \\
\hline & 24 & & & & & & \\
\hline
\end{tabular}

nomogram ranged from 3.0 to $19.1 \mathrm{mg} \cdot \mathrm{l}^{-1}$ and 0.4 to $8.9 \mathrm{mg} \cdot \mathrm{l}^{-1}$, respectively. On the other hand, peak and trough levels obtained using the rule of eights ranged from 2.3 to $12.7 \mathrm{mg} \cdot \mathrm{l}^{-1}$ and 0.2 to $5.9 \mathrm{mg} \cdot \mathrm{l}^{-1}$, respectively. Regarding the Hull-Sarubbi table, the levels ranged from 2.9 to $12.7 \mathrm{mg} \cdot \mathrm{l}^{-1}$ and 0.2 to $5.9 \mathrm{mg} \cdot \mathrm{l}^{-1}$, whereas those with the Dettli method ranged from 2.8 to $11.8 \mathrm{mg} \cdot 1^{-1}$ and 0.1 to $4.7 \mathrm{mg} \cdot 1^{-1}$, respectively.

According to Cochran's test the group's data (peaks plus troughs, peaks only and troughs only) revealed significant differences among the five nomograms for peak plus trough and peak only target range $(\mathrm{p}<0.05)$. With respect to the peak plus trough target range, the results indicated that there were significant differences between the Thomson guidelines and the other four methods $\left(\chi^{2}\right.$, $\mathrm{p}<0.05)$, whereas the Thomson guidelines achieved the highest percentage $(63 \%)$ of the predicted steady-state concentration within the target range. When only the peak target range was considered, there was a significant difference between the values of the Thomson guidelines and the Dettli method and those of the other three methods $\left(\chi^{2}, p<0.05\right)$. The Thomson guidelines and the Dettli method showed the highest percentage values (75 and $71 \%$, respectively) in predicting steady-state concentrations. When considering the predicted concentrations within the trough target range, the percentage values were approximately the same in all five methods $(p>0.05)$. The percentages of patients underdosed (peak concentration $<5 \mathrm{mg} \cdot \mathrm{l}^{-1}$ ) or overdosed (trough concentration $>2 \mathrm{mg} \cdot \mathrm{l}^{-1}$ ) by applying the five methods are presented in table 3. The Mawer nomogram produced the lowest percentage value (11\%) for peak concentrations $<5 \mathrm{mg} \cdot \mathrm{l}^{-1}$, followed by Thomson guidelines and Dettli method (21 and $22 \%$, respectively). On the other hand, empirical dosing and the Thomson guidelines showed the lowest percentages of overdosed patients ( 9 and 13\%, 
Fig. 1. Frequency distribution of the calculated and measured gentamicin peak (left) and trough (right) concentrations achieved in 56 patients based on individual estimates of $\mathrm{K}_{\mathrm{e}}$ and $\mathrm{V}_{\mathrm{d}}$, using dosage recommendations determined by five nomograms and empirical dosing. Solid bars indicate concentrations within the target range, and open bars indicate concentrations outside of the target range.
Thomson guidelines
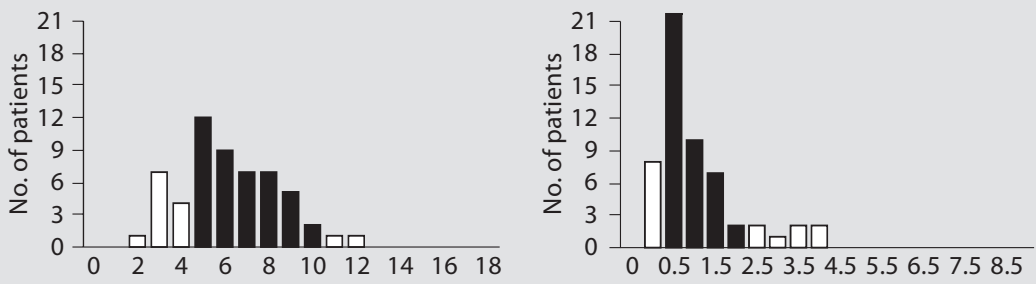

Mawer nomogram
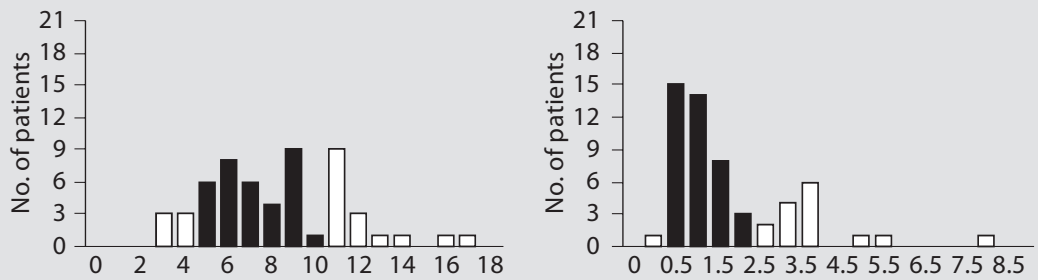

Rule of eights
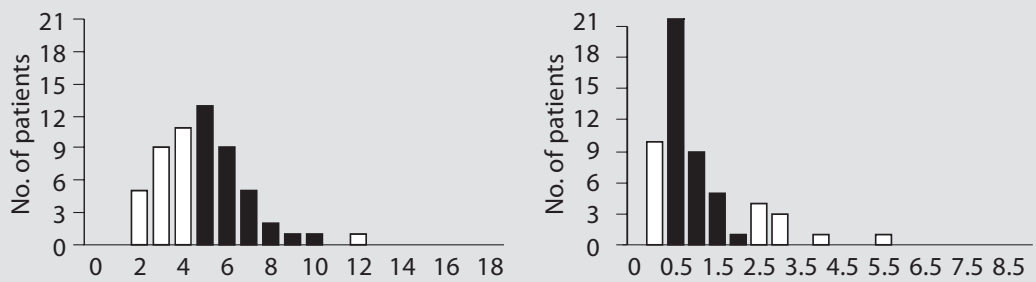

Hull-Sarubbi table
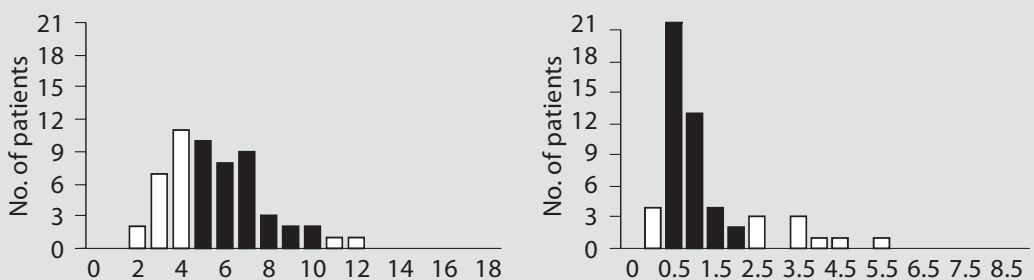

Dettli method
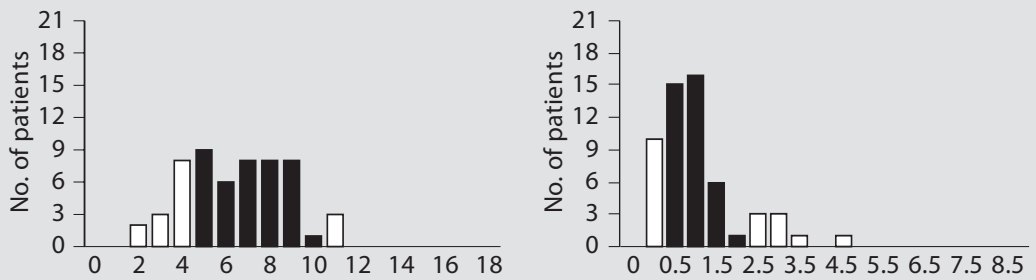

Empirical dosing
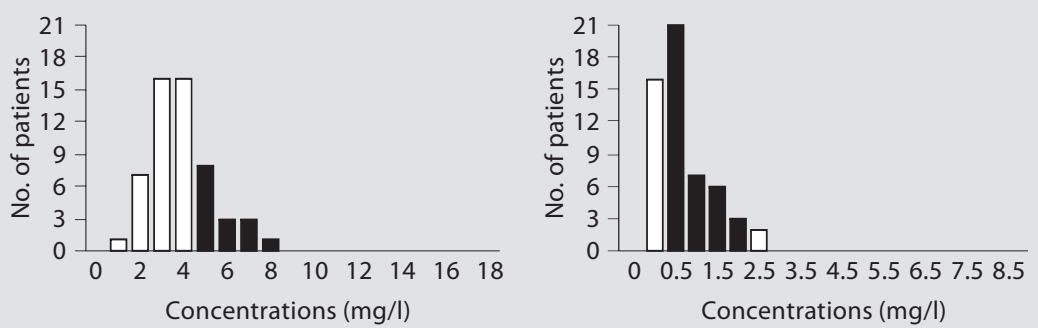
Table 2. Percentage of dosage regimen providing predicted concentrations within target peak plus trough (from 5 to $10 \mathrm{mg} \cdot \mathrm{l}^{-1}$ and from 0.5 to $2 \mathrm{mg} \cdot \mathrm{l}^{-1}$, respectively), peak only (from 5 to $10 \mathrm{mg} \cdot \mathrm{l}^{-1}$ ) and trough only (from 0.5 to $2 \mathrm{mg} \cdot \mathrm{l}^{-1}$ ) ranges

\begin{tabular}{|c|c|c|c|c|c|c|}
\hline \multirow[t]{2}{*}{ Target } & \multicolumn{6}{|c|}{ Percentage within range for each dosing method } \\
\hline & $\begin{array}{l}\text { empirical } \\
\text { dosing }\end{array}$ & Thomson & Mawer & $\begin{array}{l}\text { rule of } \\
\text { eights }\end{array}$ & $\begin{array}{l}\text { Hull- } \\
\text { Sarubbi }\end{array}$ & Dettli \\
\hline Peak plus trough & 25 & $63^{1}$ & 48 & 37 & 46 & 50 \\
\hline Peak only & 30 & $75^{1}$ & 59 & 52 & 60 & $71^{1}$ \\
\hline Trough only & 80 & 73 & 71 & 66 & 79 & 67 \\
\hline
\end{tabular}

${ }^{1}$ Significant differences among the five methods $(\mathrm{p}<0.05)$.

Table 3. Percentage of dosage regimen providing underdosing (peak concentration $<5 \mathrm{mg} \cdot \mathrm{l}^{-1}$ ) or overdosing (trough concentration $>2 \mathrm{mg} \cdot \mathrm{l}^{-1}$ )

\begin{tabular}{lllllll}
\hline Target & \multicolumn{4}{l}{ Percentage within range for each dosing method } & & \\
\cline { 2 - 7 } & $\begin{array}{l}\text { empirical } \\
\text { dosing }\end{array}$ & Thomson & Mawer & $\begin{array}{l}\text { rule of } \\
\text { eights }\end{array}$ & $\begin{array}{l}\text { Hull- } \\
\text { Sarubbi }\end{array}$ & Dettli \\
\hline Underdosing & 70 & 21 & 11 & 46 & 36 & 23 \\
Overdosing & 9 & 13 & 27 & 16 & 16 & 14 \\
\hline
\end{tabular}

respectively), followed by Hull-Sarubbi table, Dettli method and rule of eights. However, the highest number of potentially overdosed patients resulted from the Mawer nomogram (27\%).

\section{Discussion}

In the present study, the five nomograms were compared retrospectively. The main drawbacks in conducting such types of study are the accuracy of the documented times for drug administration and blood sample withdrawal. The potential errors in the timing of the doses were minimized by checking two record sheets; the patient drug sheet and the nursing chart. Concordant biochemistry and nursing chart records were used to minimize errors in the timing of blood samples. In addition, these problems were also minimized in the current study by using the same set of patient data for comparison [6].

A prerequisite for achieving steady-state peak and trough concentrations for gentamicin within the therapeutic range is the estimation of pharmacokinetic parameters in individual patients (e.g. clearance or $\mathrm{K}_{\mathrm{e}}$ and $\mathrm{V}_{\mathrm{d}}$ ). Several parameter estimation programs, including Bayesian program, have been introduced to provide an accurate interpretation of gentamicin drug concentrations [2, 22, 23]. In this study, the $\mathrm{K}_{\mathrm{e}}$ and $\mathrm{V}_{\mathrm{d}}$ were calculated for each patient using a modified two-point Sawchuk-Zaske method [19]. The estimates of $K_{e}$ and $V_{d}$ were then used to predict the gentamicin peak and trough concentrations that would result from the dosage recommendations produced by the five nomograms.

In this study, a high percentage of steady state peak concentrations resulting form empirical dosing were outside the desired therapeutic range. Therefore, initial gentamicin dosing based on patient demographic characteristics and population information is required to obtain a desired concentration more frequently. The comparative results indicated that the Thomson guidelines performed significantly better than the other four methods and empirical dosing in predicting peak plus trough and peak only target concentrations. The Mawer nomogram, the Hull-Sarubbi table and the Dettli method produced similar results when predicting the steady-state concentrations and were significantly better than the rule of eights and empirical dosing.

In addition to the high performance achieved by the Thomson guidelines, this method has the advantage of simplicity and requires minimum effort for calculation. For example, the Thomson guidelines only require the 
use of a nomogram to estimate creatinine clearance, followed by reference to a table to obtain the dosage recommendation. The method has practical merits for most physicians in the ward situation. However, the peak concentrations predicted by the Thomson guidelines should be given attention where around $21 \%$ of the calculated peak concentrations were $<5 \mathrm{mg} \cdot \mathrm{l}^{-1}$ and this would limit its use in patients with life-threatening infections [6]. From the toxicity point of view, as indicated by the trough concentrations $>2 \mathrm{mg} \cdot \mathrm{l}^{-1}$, the Thomson guidelines would be expected to produce the lowest gentamicin toxicity.

In contrast, the Dettli method requires an ability to use pharmacokinetic equations to obtain the dosage regimen, and the results could vary according to the actual target concentrations chosen. Therefore, this method would be difficult to apply in a clinical setting. In addition, the Dettli method produced approximately $14 \%$ of the calculated trough levels $>2 \mathrm{mg} \cdot 1^{-1}$, indicating a potential toxicity when utilizing this method. In contrast, the prescribed dosing, rule of eights and Hull-Sarubbi methods are not recommended because they produced 70,46 and $36 \%$ of peak concentrations, respectively. The
Mawer nomogram, on the other hand, is the preferred method with respect to the calculated peak concentrations, which were $<5 \mathrm{mg} \cdot \mathrm{l}^{-1}$, but in $30 \%$ of the patients the levels were $>10 \mathrm{mg} \cdot \mathrm{l}^{-1}$. The potential toxicity is expected to be higher with this method as the calculated trough concentrations were $>2 \mathrm{mg} \cdot \mathrm{l}^{-1}$.

\section{Conclusion}

The results show that a large number of patients (3763\%) were outside the target ranges in all initial gentamicin dosing methods evaluated in this study. Therefore, serum concentration measurement can be advised to assist in the optimization of gentamicin dose selection.

\section{Acknowledgments}

The authors are grateful to Dr. Isam Albahu, head of Pharmacy Department, Al-Amiri Hospital, Dr. Tarik Aljassar, director of Al-Amiri Hospital, Dr. Molly, a consultant clinical microbiologist at Al-Amiri Hospital, and the clinical biochemistry staff, Al-Amiri Hospital.

\section{References}

- 1 Koo J, Tight R, Rajkumar V, Hawa Z: Comparison of once-daily versus pharmacokinetic dosing of aminoglycoside in elderly patients. Am J Med 1996;101:177-183.

-2 Staatz CE, Bryne C, Thomson AH: Population pharmacokinetic modeling of gentamicin and vancomycin in patients with unstable renal function following cardiothoracic surgery. Br J Clin Pharmacol 2006;61:164176.

3 Anaizi N: Once-daily dosing of aminoglycosides - A consensus document. Int J Clin Pharmacol Ther 1997;35:223-226.

-4 Barza M, Ioannidis JPA, Cappelleri JC, Lau J, Smail F: Single or multiple daily doses of aminoglycosides: a meta-analysis. Br Med J 1996;312:338-345.

$\checkmark 5$ Nicloau DP, Wu AH, Finocchiaro S, Udeh E, Chow MS, Quintiliani R, Nightingale C: Once-daily aminoglycoside dosing: Impact on requests and costs for therapeutics drug monitoring. Ther Drug Monit 1996;18:263266.

6 Thomson AH, Campbell KC, Kelman AW: Evaluation of six gentamicin nomograms using a bayesian parameters estimation program. Ther Drug Monit 1990;12:258-263.

7 Gilbert DN: Editorial response: meta-analyses are no longer required for determining the efficacy of single daily dosing of aminoglycosides. Clin Infect Dis 1997;24:816-819.
-8 Al-Lanqawi YM, Capps P, Abdulmalik K: Therapeutic drug monitoring of high dose gentamicin in an elderly patient: a case report. Med Princ Pract 2005; 14:363-365.

$\checkmark 9$ Gilbet DN: Once-daily aminoglycoside therapy. Antimicrob Agents Chemother 1991;35: 399-405.

10 Parker SE, Davey PG: Practicalities of oncedaily aminoglycoside dosing. J Antimicrob Chemother 1993;31:4-8.

-11 Hatala R, Dinh TT, Cook JD: Single daily dosing of aminoglycoside in immunocompromised adults: a systematic review. Clin Infect Dis 1997;24:810-815.

12 Ali ZM, Goetz BM: A meta-analysis of the relative efficacy and toxicity of single daily dosing versus multiple dosing of aminoglycosides. Clin Infect Dis 1997;24:796-799.

13 Mawer GE, Ahmed R, Dobbs SM, McGough JG: Prescribing aids for gentamicin. Br J Clin Pharmacol 1979;1:45-50.

14 Lesar TS, Rotschafer JC, Strand LM, Solem LD, Zaske DE: Gentamicin dosing errors with four commonly used nomograms. JAMA 1982;248:1190-1193.

15 Hull JH, Sarubbi FA: Gentamicin serum concentrations: pharmacokinetics. Ann Intern Med 1979;85:188-189.

16 Dettli LC: Drug dosage in patients with renal disease. Clin Pharmacol Ther 1974;16:274280 .
17 Zaske DE, Cipolle RJ, Rotschafer JC, Solem LD, Mosier NR, Strat RG: Gentamicin pharmacokinetics in 1,640 patients: method for control of serum concentration. Antimicrob Agents Chemother 1982;407-411.

18 Siersbaek-Nielsen K, Mølholm Hansen J, Kampmann J, Kristensen M: Rapid evaluation of creatinine clearance. Lancet 1971;1: 1131-1134.

19 Sawchuk RJ, Zaske DE: Pharmacokinetics of dosing regimens which use multiple intravenous infusions: gentamicin in burn patients. J Pharmacokinet Biopharm 1976;4:183-195.

20 Fleiss JK: Statistical Methods for Rates and Proportions, ed 2. New York, Wiley \& Sons, 1981

21 Cavanson GC: Applied Probability and Statistical Methods. Boston, Little Brown, 1984.

22 Kelman AW, Whiting B, Bryson SM: OPT: a package of computer programs for optimization in clinical pharmacokinetics. Br J Clin Pharmacol 1982;14:247-556.

23 Zandvoort FA, Wagenvoort HT, Derkx FHM, Michel MF: Evaluation of a microcomputer program (OPT) for parameter optimization in clinical pharmacokinetics. Br J Clin Pharmacol 1987;24:511-518. 